University of Rhode Island

DigitalCommons@URI

Open Access Master's Theses

1973

\title{
Human Self-Punitive Behavior During Uncertainty of Delivery Time of Unavoidable Shocks
}

Thomas H. Walsh

University of Rhode Island

Follow this and additional works at: https://digitalcommons.uri.edu/theses

\section{Recommended Citation}

Walsh, Thomas H., "Human Self-Punitive Behavior During Uncertainty of Delivery Time of Unavoidable Shocks" (1973). Open Access Master's Theses. Paper 1721.

https://digitalcommons.uri.edu/theses/1721

This Thesis is brought to you for free and open access by DigitalCommons@URI. It has been accepted for inclusion in Open Access Master's Theses by an authorized administrator of DigitalCommons@URI. For more information, please contact digitalcommons-group@uri.edu. 
HUMAN SELF-PUNITIVE BEHAVIOR DURING UNCERTAINTY OF DELIVERY TIUE DP UNAVOIDABIE SHOCIKS

BYY THOKLS H. WALSH

MHSTE'S MHESIS SUBMITTED TO THE PSYCHOLOGY DEPARTMEN IN PARTIAI FULFILIMENT OF THE REQUIREMENTS FOR THE DEGREE OF MASTER OF ARTS

IN PSYCHOLOGY

UNIVERSITY OF RHODE ISLAND 1973 


\section{ABSTRACT}

Twenty psychology graduate school subjects, ten males and ten females, established their cwn levels of aversity for two series of ten each unavoidable eiectric shocks, with each shock lasting 2.5 seconds and scheciuled to be delivered automatically every 30 seconds. Condition \#1 (high predictability) subjects could see a timer and know when 30 seconds had passed Condition \#2 (10w predictability) subjects could not. All subjects could push a button and self-administer shocks at will. The data did not support the hypotheses that low-predictability subjects would self-administer more shocks and would take less total time for the series of shocks. Females self-administered fewer shocks and took longer time in the low predictakility condition, and these data were correlated with their higher scores on measures of anxiety. Subjects preferred to set their own levels of electric shock and set then higher thas. previously reported in the literature subjects reported that they could have tolerated many more than the twenty shocks. These results and paper and pencil responses of post-tests of anxiety were interpreted as contributing valuable information to the sparse literature on punishrent with human subiects. 


\section{ACKNOWLEDGMENTS}

My thanis are extended to Dr. Nelson F. Snith, for his enthusiastic suggestions and generosity or time; in adaition, were it not for his technical assistance in setting up the apparatus, this research would not have been possible. I also rave much appreciation to Dr. David S. Camp not only because he contributed time and interest in suggesting related research, but also because he kindly motivated ne to overcome a lassitude which had interfered with the completion of this research. The cooperation, patience, and understanding of Dr. Allan Berman and of $\mathrm{Dr}$. Peter $\mathrm{F}$. Merenda are gratefully acknowledged; and may every student be as fortunate as I to have enisted a non-department member such as Dr. Joel A. Cohen (Department of Kistory) who unhesitatingly agreed to serve on ny research committee. 


\section{TABLE OF CONTENTS}

Abstract................................iii Acknowledgements..........................iv List of Tables............................vi List of Figures.......................... vii

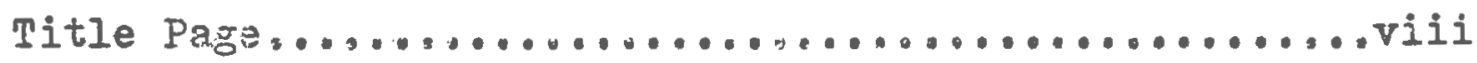

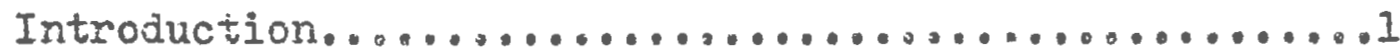

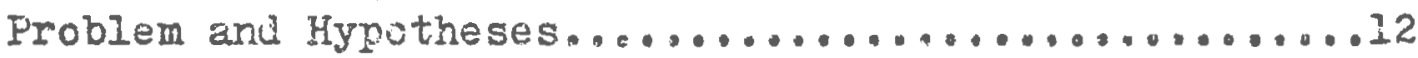

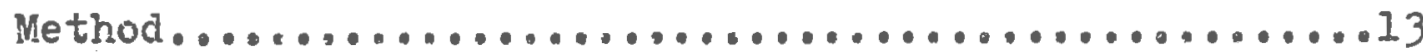
Results...............................16

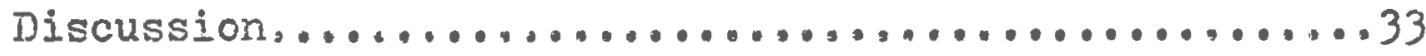
Appendix...................................44 Bibliography................................69 


\section{IIST OF TABLES}

Table

Page

1. "Severity of a Funishment" or Aversiveness... 9

2. Means of Number of $S \in l f$-Administered shocks........................... I?

3. Means of Number of Attempts to SelfAdminister Shock...................... 2 I

4. Means of Amount of Time in Seconds Taken During mrials................. 23

5. Percentages of Haximum Allotted Time (325 secs.) For Each 10 Trials Taken by subjects............................ 29

6. Mear Anxiety Sccres on Zuckerman Miultiple Affect Adjective Check List............. 31

7. Mean Milliamp Settings for Electric Shock Set by subjects..................... 32

8. Subjects' Responses to Post-Test Questions About Pain, Number of Shocks, and Preferences....................... 34

9. Subjective Post-Test Descriptions of Shock Experience 


\section{IIST OF FIGURES}

Figure 1. Interaction effect between sex and predictability on total number of selfadministered shocks.....................19,20

Figure 2, Interaction effect between sex and predictability on total time in seconds for trials $1-10 . \ldots \ldots \ldots \ldots \ldots \ldots \ldots \ldots \ldots \ldots \ldots . \ldots . \ldots . . \ldots 22,23$

Figure 3 Interaction effect between sex and predictability on total time in seconds for trials

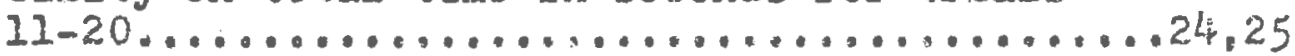


HUMAN SELF-FUNITIVE BEHAVIOR DURING UNCERTAINTY OF DELIVERY TIME OF UNAVOIDAEIE SHOCKS 
The literature dealing with the constructs of anxiety and fear is extensive. Anxiety, like fear and anger arises in response to danger. Cannon (1916) noted biological aspects of these emotions; i.e., increased respiration and blood pressure and number of red corpuscles set free by the spleen, to prepare the body for right or flight. Anxiety was referred to as a state of arousal by Berlyne (1960). Some theorists have proposed that the term "anxiety" should be reserved for fear arising from an unknown source, and that the term "fear" should be assigned to awareness of a threatening specific object or source. Measured physio$\log$ ically, the human body reacts in much the same way whether the anxiety is related to specific or diffuse objects (Levitt, 1967). Hilgard and Atkinson (1967) referred to anxiety as a state of apprehension related to fear. Ferster and Ferrott (1968) mentioned anxiety as a state of the organism; they referred to changes in performance produced by an aversive stimulus. It is interesting that in more and more psychology textbooks, the "Subject Index" listing for anxiety is followed by "See Fear" (Boe and Church, 1968). Skinner (1938) referred to anxiety as a behavior fattern observed during the interval between a Eignal and an unavoidable aversive stimulus. Mowrer (1938) presented humans with a painful stimulus. Post-experimental subjective reports of the experience included the descriptions 
"anticipation," "dread," "apprehénsion," "expectancy," "anxiety." For all practical purposes, anxiety and fear are indistinguishable (Levitt, 1967).

In experimental psychology, fear (anxiety) has often been treated as a learned response. Under classical conditioning, the presentation of UCS (shock) will elicit in the rat behaviors such as defecation, urination, freezing, whining, which are evidences of an emotion which can be called anxiety. With successive pairing of a CS (tone, light) with UCS, the subsequent presentation of CS alone will elicit similar respondents.

Anxiety may also be corsidered a learned (secondary) drive, or a reaction to a $C D$, based on the organism's innate tendency to avoid pain (Levitt, 1967). This is aemonstrated typicaily with a two compartment box (Miller, 1948). When shock in compartmant $A$, within a few trials the rat will escape through a coor to non-shocked compartment B. In subsequent trials, when placed in compartment $A$, with no UCS, the rat still rurs to $B$. Mowrer theorized that the stimuli accompanying placement in compartment $A$ i.e. the tone, grid, or color all served as CS's (anxiety) to evcke the motivating conditioned response of anxiety. The arcidance response of running in negatively reinforced by the reduction of the conditioned anxiety. This behavior is very resistant to extinction. This process is generally referred to as Mowrer's two-factor theory of avoidance, a combination of classical and operant conditioning, and is 
thought to be analagous to the process underlying phobias in humans.

The punishment procedure has usuaily been defined as one in which a response is followed by an aversive stimulus in order to decrease its frequency of occurrence (Kanfer and Phillips, 1970). However, there are many studies with animals (e.g. Gwinn, 1949; Melvin, 1964; Brown, et al, 1964) to support the observation first made by Mowrer (1947) that punishment during extinction of avoidance behavior resulted in increased frequency of that response and increased resistance to extinction. If a small section of the grid floor at the far end of the alley near compartment $B$ was permanently electrified so that the rat had to get $a$ shock in running from start box $A$ to safety compartment $B$, the running behavior apparently did not extinguish. Even though the rat never again experienced shock in $A$ flight from $A$ to $B$ continued (Candland, 1968). I'wo factor avoidance theory attempts to explain this phenomenon by suggesting that the purishment which is a consequence of his running arouses more anxiety, and his learned responses to anxiety increase. Nowrer (1947) related such paradoxical behavior to the "compulsive," "selfdefeating," "masochistic" behavior which Horney (1937) and Mowrer and UIlman (1945) discussed under the concept of the "vicious circle." It is of interest that when punishment is administered under special conditions, the aversively motivated response of running could be either enhanced or 
inhibited during extinction. Pfitshinent applied near a resulted in faster running and greater resistance to extinction than punishment appliê, near B. Timpbell, Smith, Misanin, 1966).

When the organism is shocked in running from $A$ during either avoidance training, escape training, avoidanceescape training, or punished extinction, punishment tends "to elicit the response of forward locomotion" (Brown, 1969: also Gwinn, 1949).

Many studies have investigated the significance of a stimulus signaling the cccurrence of shock. In an avoldance situation, Sidman and Boren (1957) found that rats responded to termirate a warning signal as soon as possible even though that behavior was followed by delayed shock. This response was preferred to the alternative of postponing the delayed shock and prolonging the warning signal. While this is animal benavior and there were only four subjects, the results tended to support the observation that anticipation of pain may be more aversive than the pain itself. The Sidman and Boren study is inconsistent with other studies emphasizing the predictability ralue of a warning signal in unavoidable shock conditions. Lockard (1963) shocked rats, which were free to roam, on both sides of a two compartment box. On the "predictable" side, each unavoidable stock was preceded by a warning signal; on the "unpredictable" side, there was no warning signal. Rats spent most of their time (90 per cent) on the "predictable" 


\section{5}

side during acquisition, and only durlrig extinction did they divide their time equally between the two compartments. In testing the specific hypothesis that signal-shock would be selected over shock-signal, Perkins, et al, (1963) ran 16 rats in a shuttle box for an eleven-hour session on each of six successive days, and gave them six shocks at irregular intervals every half hour regardless of what they did. On oneside of the box, each 0.5 seccnd shock was preceded by a signal light for three seconds; on the other side, a 0.5 second shock preceded a three second signal light. By the end of the day, subjects spent more than 75 per cent of their time on the signal--shock side; by the third day, almost 90 per cent of their time. Brimer and Kamin (1963) and Camp (1968) reported greater suppression of bar-pressing for food in rats receiving non-signaled shocks than receiving Eignaled shocks.

In testing the informational value of a warning signal, Badia, et 2l, (1966) found humans to have a preference for imriediate 100 pen cent shock with nowarning signal. But these same subjects preferred a warning signal before a four second delayed shock administered 25 per cent of the time over immediate shock 25 per cent of the time. The latter difference was not statistically significant and the number of subjects was swall. These findings were reversed in a study with a larger number of subjects (Badia, et al, 1967) and they concluded that most humans appear to prefer information (warning 
signal) preceding an aversive event. Thus, receiving shocks without a warning signal is more aversive.

In an unavcidable shoch situation rats preferred irmediate over delayed shock. Knapp, et al, (1959) demonstrated this preference by placing hungry rats in a T-maze and allowing them to run for food. On one side, they received immediate shock in the chamber; on the other, shock was delayed 30 seconds. D'Amato and Gumenik (1960) showed that human males in an unavoidable shock situation, preferred a lever that produced immediate shock to a lever that led to randomly delayed shock of equal intensity which they later "judged as more unpleasant." Cook and Barnes (1964), in testing a redaction of Hull's reinforcement theory (Corollary 111), " found that humans "tended to "choose immediate rather than delayed shock when faced with timedelay options of $0,2,4,6,8$ seconds, following a CS (light). The intensity and duration of shock was not known; there were only six trials,--five with shock; the delays were fixed, not variable, subjects were all males; and there was no statistical treatment of data. This tendency followed a shallow U-shaped curve over trials for 0-delay about which one might speculate as follows: at first, anxiety arose because of uncertainty about shock experience and this anxiety motivated the subject to take immediate shock. The

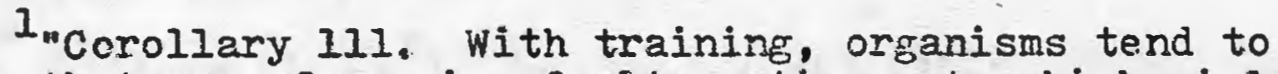
choose that one of a pair of alternative aets which yields reinforcement with the lesser delay." (Hull, C.L., 1943). 
shock experience relievedthe anxiety for the next few irials, then the knowladge that the last trial was due motivated the subject to get it over with. (Interpretation mine.) Pilot data obtained from only two males and two females (walsh, 1970) showed all subjects when allowed to self-administer a fixed number of unavoidable shocks, did so as soon as possible "to get it over with." Cook and Barnes also found two groupings of subjects in the high shock group: those who consistently selected immediate shock and those who consistently preferred delayed shock. Personality variables as well as stimulus variables were both probably contributing to findings. Church (1964) ackrowledged that ever rats may demonstrate different degrees of suppression because of individual differences in resistance to shock, or momentto-moment variability of an individual rat.

Daie (1963) found a behavior pattern similar to that of Cook and Barnes with 142 students, where the UCS was verbal threat rather than electric shock. A quiz in an introductory psychology course has been graded and returned. All students were telephoned on a sunday and told that the professor had raised some questions on their grades and on the adequacy of their answers. They were told the professor wanted to see them and would they telephone for an appointment, he was available from 8:00 to 5:00 Monday through Friday. Only 50 per cent of students called to make appointments: 46 for Monday; 19 for Tuesday: 5 for Weảnesday, 1 for Thursday, $O$ for Friday. Thus, the majority of students 
chose immediate punishment rathe than delayed punishment. In another more comprehensive study, cook and Bernard (1965) found that trale and fenale subjects chose a short delay of punishment. They also found this was true for males (females not tested) whether shock was inevitable or probable (shocked on all 10 trials, 9 of 10 trials, 7 of 10 trials, 5 of 10 trials, 3 of 10 trials, 1 of 10 trials). They found that no psychophysiological measures (treathing rate, heart rate, GSR) related either to gradually increasing anxiety with expectation of UCS or to decreasing anxiety after UCS cessation. They did find a momentary change in GSR asscciated with CS (signal light) which they termed a measure of arousal and not of anxiety. Cthers (Lacey, 1959; Lang, 1968) have pointed out that there is frequently little correspondence in autonomic. verbal, or overt motor measures of anxiety. Discrepancies between physiological and verbal reports are common. The nature of UCS is important. Camp, et al, (1967) found with rats that the greater the irtensity of the punisinment, the greater the suppressicn of appetitive response. Campbel1, Smith and Misanin, (1966) denonstrated that punishment had more suppressing results on rat response with shock duration of 1.5 secords than with 0.15 second duration. In the research with humans, electric shock has varied from 1.5 milliamps (MA.) to $2.25 \mathrm{MA}$, with durations of 0.1 second to 1.0 second (see Table 1). Also, there have been fewer shocks ( 5 to 20 ) administered to humans than to rats (typically 
9

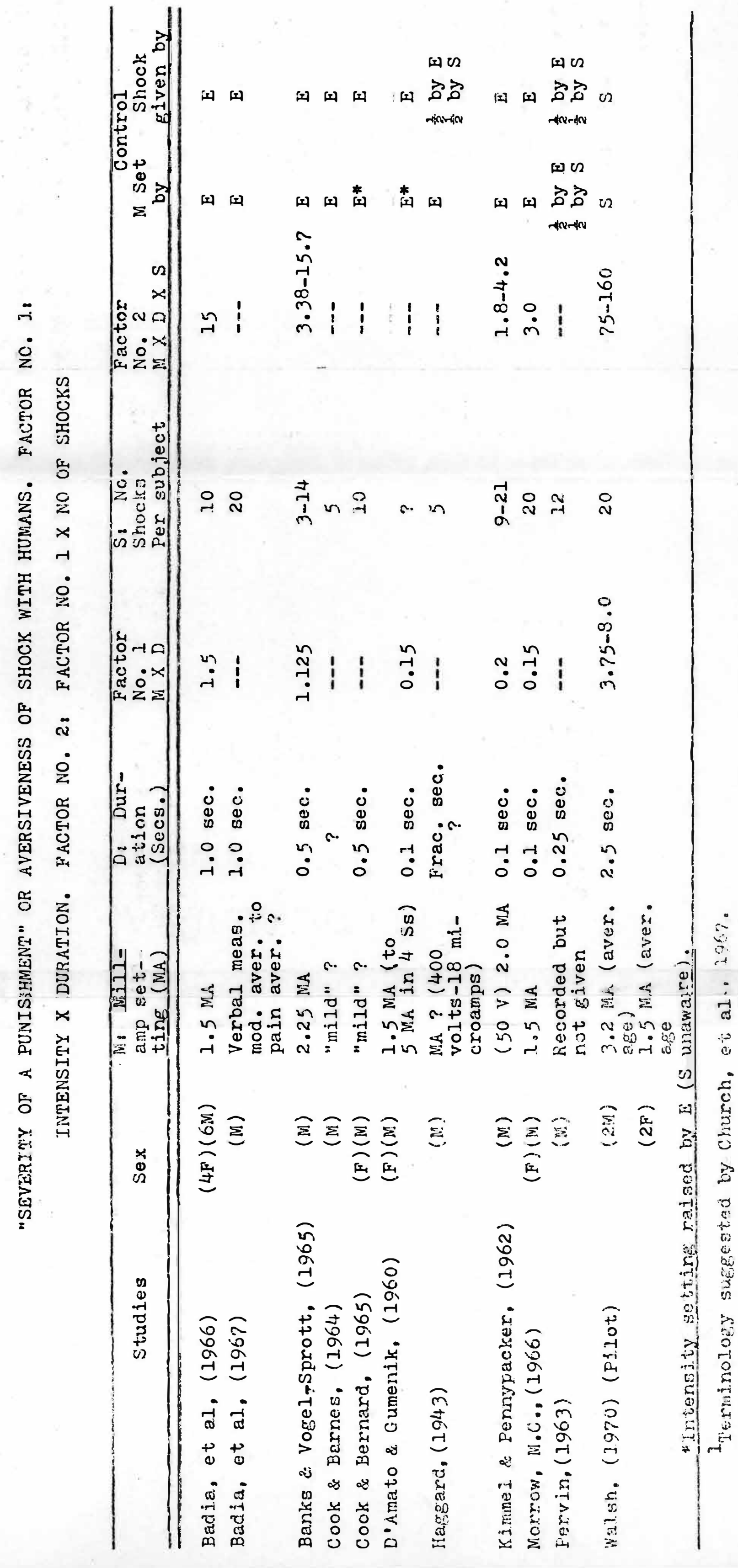


in the 100 's, e.g. 132 in Perkins, et al, (1963). The small protoplasmic mass of the rat gets more shocks at higher intensities for longer durations than humans. We know more about punishment with rats than we do with humans. Solomon (1964) has pleaded for more research on punishment with humans. Perhaps there should be a UCS factor (intensity $x$ time $x$ number of shocks) to guide future meaningful human punishment experiments, One of the findings of implosive therapists is that humans can endure much more anxiety than therapists had thought. Church, et al, (1967) suggested an operational term "severity" of punishment, consisting of MA $x$ time, They found that intensity and duration combine in a simple fashion, and that severity was directly related to the amount of response suppression in rats. It would be helpful if such information were included in every published research for both animal and human subjects.

Few studies with humans have been concerned with anxiety in an unavoidable shock situation where the subject could self-administer the shock. Haggard (1943) compared nine "E-shock" (experimenter-administer shock) subjects with nine "S-shock" (self-auminister shock) subjects in a test situation where all subjects were read 42 stimulus words among which a two-word sequence "sharp, sword" was randomiy presented five times. Shock followed "sharp, sword" for all subjects, but the S-shock subjects were also given a signal light. Haggard found that subjects who could selfadminister shocks showed significantly less anxiety, as 
measured by GSR, than did subjects given shock by experimenter. A post-test session showed the S-shock subjects to have more accurate estimates of the number of shocks given and the number of stimulus words presented. Pervin (1963) tested humans in combinations of shock in a $3 \times 2$ experimental design, signal, no signal, inconsistent signal and "control" (self-administer shock), "no control." After presentation of each pair of conditions, subject expressed 3. preference for one of the conditions. Paired comparison data showed significant preferences for: signal Vs. nosignal, signal vs. inconsistent signal; inconsistent signal Vs. no-signal. These preferences decreased over sessions. They also found a control vs. no-control to be significant for only the zecond of three sessions. Post-test paper and pencil subjective ratings showed more pain and anxiety with no control (experimenter administened shock), but the ratings were not significant.statistically.

This review of the literature has shown that some of the pertinent variables in the human punishment situation are: (1) presence or absence of a warning signal; (2) time of onset of UCS, whether immediate, fixed delay, or variable delay, following a signal; (3) probability of the UCS; (4) controllability of the UCS by subject, (5) duration of the UCS, (6) intensity of the UCS: (7) number of UCS's. Not much is known about the last four variables. In most of the studies, a small number of shocks has been presented at a low or unknown intensity and for a 
short duration. Only a few sulutets have considered selfadministration of the shocks.

Lockard (1963) associated the wore" "predictable" with a warning signal for shock, and she showed that rats spent most of their time on the predictable side of the box. Humans have also been more anxious in unpredictable situations (Pervin, 1963). Predictability is a variable which has not been studied sufficiently with humans.

\section{Problem and Hypotheses}

The present study examined the effects of the predictability variable of shock in a situation in which 20 unavoidable shocks were administered. The subjects had the option of self-administering any of the 20 shocks in either the predictable or unpredictable situations. Predictability was varied in two conditions. Condition No. I was one in which the subject saw an electric timer and knew when the shock would be administered automatically. Condition No. 2 was one in which the timer was covered, and, thus the subject did not know exactly when the shock would occur. In both conditions, the subject was able to self-administer shock by pressing a button, and the shock level was set by the subject himself. It was hypothesized that low-predictability subjects (no CS, i.e., no visible timer): wculd:

(1) self-administer more shocks.

(2) attempt to self-administer more shocks. (Because of UCS duration of $2 \frac{1}{2}$ seconds, there may be ineffective attempts to self-administer shocks 
(3) receive the allotted rutioter of shocks in less time.

(4) be more anxious.

(5) It was also hypothesized that all subjects would set their own levels of UCS intensity at a nigher level than established in the literature.

The dependent variables were:

(I) measure of time to take all shocks:

(2) the number of effective self-administered shocks

(3) the number of attempts to self-administer shocks;

(4) the shock levels set by the subjects:

(5) paper and pencil measures of "state" anxiety as measured by: (A) Zuckerman's Multiple Affect Adjective Check Iist, and (B) Wolpe's selfrating SUD scale;

(6) Post-test subjertive reports.

\section{Nethod}

Subjects

Surjects were 10 male (mean age 25.9 years) and $10 \mathrm{fe}-$ males (mean age 27.8 years) graduate student volunteers fron the University of Rhode Island. Both male and female subjects were randomly assigned in equal numbers to the two conditions of timer visible and timer covered.

\section{Apparatus}

The apparatus consisted of a C.J.A. Model:250 
Stimulator Unit which produced a constant current stimulus of 0 to 5 kia. Standard programming equipment was used consisting of timers, relays, pulse duration controls, and a hand push button. UCS (electric shock) was given through two electrodes inserted in a leather wrist cuff attached to the wrist of the non-preierred hand. There was one counter to record the number of shocks taken automatically, another counter registered the total of self-administered shocks plus the total attempts to self-administer shock.s. The subject was run in an isolated room.

\section{Procedure}

Subjects were run individually. In the pre-test situation, they were first given the Zuckerman Mitiple Affect Adjective Check Iist and asked to respond on the basis of whether the adjective describes them "now." They were also asked to rate themselves on present state of anxiety on the Wolpe SUD scale. They were asked to check quickly their normal toleration for pain as being "low," "medium," or "high.". Then the following instructions were given.

Standard Instructions for Condition No. 1 (High Predictability)

1. Please sit in the chair in front of the apparatus.

2. This is an experiment in which you cannot avoid or escape shock. You are assured that no danger is involved.

3. The experimenter will assist you in attaching to your non-preferred wrist a cuff containing two electrodes. 
Electrode jelly will be applised to insure good conductance. 4. Adjust Knob $A$ of the apparatus (dial covered so setting is not visible to subject, but miay be recorded by experimenter) until you feel a stimulus which you rate as aversive to you. There will be a two-minute interval after the first 10 shocks when you will be asked to reestablish a level of aversiveness.

5. You will be given a total of 20 shocks, one shock administered every 30 seconds. Each shock lasts $2 \frac{1}{2}$ seconds.

6. Please observe Timer B. It will indicate to you the passage of 30 seconds.

7. Hold this push-button in your other hand. This buttion gives you control of the shock. If you push the button, the shock is presented immediately and will last for $2 \frac{1}{2}$ seconds after which the timer resets and begins a new 30 second cycle. You will receive a total of 20 shocks whether you push the button or not.

8. Please concentrate and do not ask questions during the experiment.

Standard Irstructions for Condition No. 2 (Low Predictability)

The instructions were the same as for Condition No. 1 , except in item No. 6 (above). Subjects were shown a timer, then it was covered, and subjects were told not to attempt to count.

AII subjects of both groups were given the wolpe SUD scale during the two-minute interval after the first 10 shocks, and again after the second 10 shocks. Condition No. 1 
subjects, in post-test, were siked to dessribe their anxiety, if any, as "increasing," "the same, "or "decreasing" as they watched the approaching end of 30 seconds on the timer.

All subjects of both Conditions were asked if they could have tolerated more than 20 shocks, and if so, (I) to give an estimate of how many: (2) would they have preferred experimenter to have set the intensity of shock; (3) could they have endured, without too much discomfort, a higher intensity of shock, and (4) was the shock a pain or pleasure experience.

\section{Results}

Because the sample in each cell was small ( $N=5$ ) and the data appeared scattered, a statistical test of homogeneity of variance (conditions $x$ triais $x$ sex) was performed; the result was homogeneity for the data of time (p).05).

Number of self-administered shocks

Table 2 shows the means of the effective number of self-adrinistered shocks. The means tended to show no difference in high predictability vs. low predictability. Pemales appeared to have self-administered fewer shocks than males for trials 1-10, but they self-administered the same number of shocks as males in trials 11-20. The means were higher for both sexes in trials 11-20. An analysis of variance (three factor mixed design, predictability, sex, trials, with repeated measures on one factor, trials) of the data showed no difference between high-predictability 
TABLE 2

MEANS OF NUMBER OF SELF-ADMINISTERED SHOCKS

\begin{tabular}{|c|c|c|c|c|c|c|}
\hline \multirow[b]{3}{*}{ Males } & \multicolumn{3}{|c|}{ High Fredictability } & \multicolumn{3}{|c|}{ Low Predictability } \\
\hline & $\begin{array}{c}\text { Trials } \\
1-10\end{array}$ & $\begin{array}{r}\text { Mrials } \\
11-20\end{array}$ & Average & $\begin{array}{c}\text { Trials } \\
1-10\end{array}$ & $\begin{array}{r}\text { Trials } \\
11-20\end{array}$ & Average \\
\hline & 8.4 & 9.4 & 8.9 & 9.6 & 9.8 & 9.7 \\
\hline Pemales & 7.6 & 10.0 & 8.8 & 7.2 & 8.6 & 7.9 \\
\hline Totals & 8.0 & 9.7 & 8.85 & 8.4 & 9.2 & 8.8 \\
\hline
\end{tabular}


and low predictability ( $F C 1$, see sear squares, Appendix, page 51). Although females self-admiristered fewer shocks than maies this was not significant ( see mean squares, Appendix, page 5i). There were more selfadministered shocks in trials 11-20 than in trials 1-10 $(F=7.66$, df $1 / 16, p .<.025)$. This difference was not significant for $\operatorname{sex}(F=2.06)$ or for conditions of predictability $(F(1)$. The amount of difference was not significant for sex $(F=1.64)$ ior for predictability $F=1.54$ : see mean squares, Appendix, page 53).

Because there was no trial-to-trial data collected, and because the above statistics compared trials 1-10 with trials Il-20 as two groups, it was decided to look at total data for all 20 trials. A treatment by levels design of analysis of variance on the total number of self-administered shocks for all subjects for all trials showed an interaction effect (see Figure 1): femaies with low predictability self-administered fewer tctal shocks (took more shocks automatically) than females with high predictability, also fewer total self-administered shocks than males in both conditions $(F=7.68$, df $1 / 16, p<.025:$ see mean squares, Appendix, page 52):

Number of attempts to self-administer shocks

The means of attempts to self-administer shocks are shom in Table 3. They showed females attempting to selfadminister fewer total shocks than males in both conditions. The means for females are all smaller than the means for 
Fig. 1. Interaction effect cetween sex and predictability on total number of self-administered shocks. 


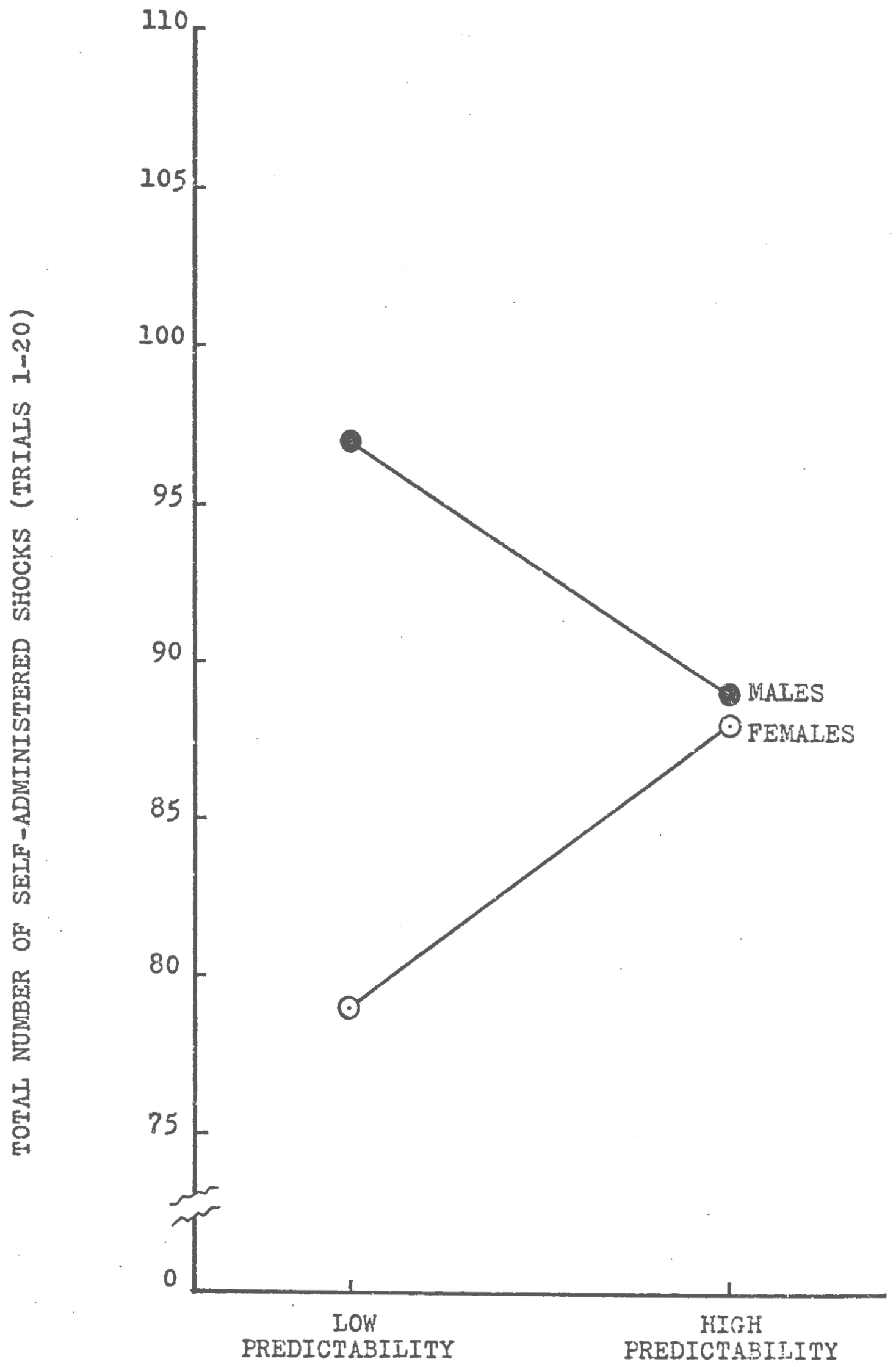


TABLE 3

MEANS OF NUMBER OF AITEMPTS TO

SELF-ADMINISTER SHOCK

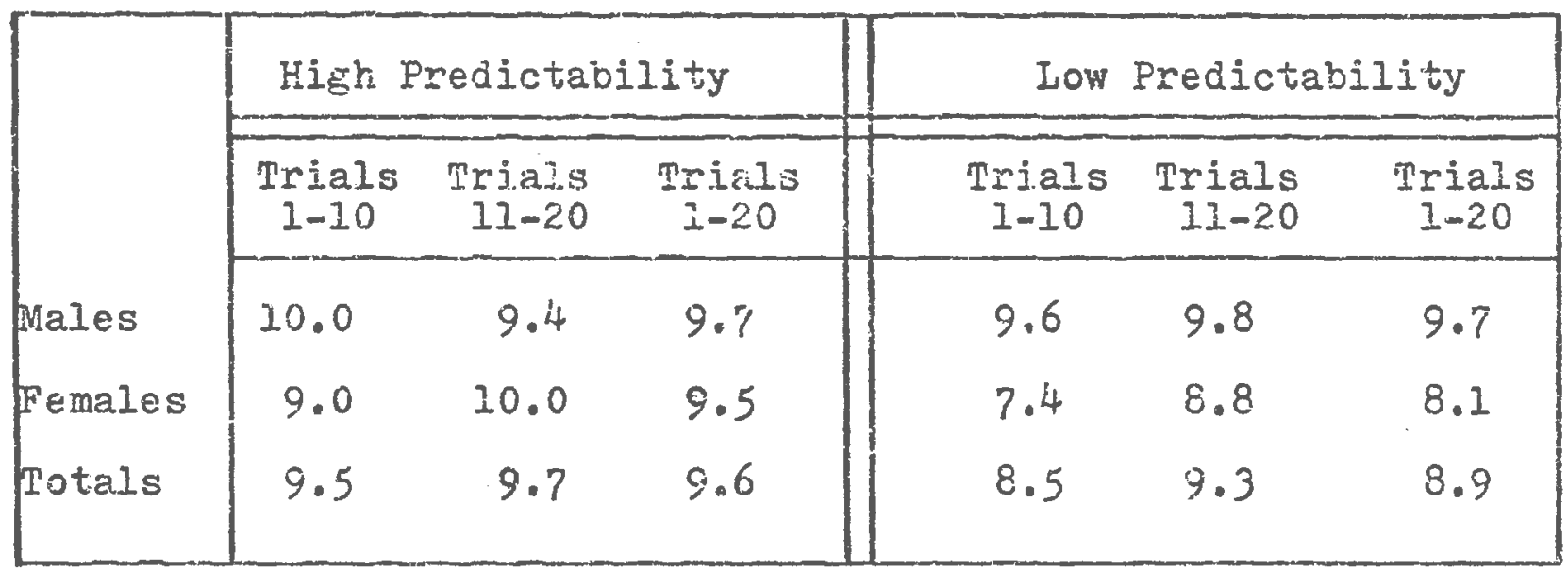


males, except in trials 11-20 in high predictability. The total means (both sexes) are smaller for trials 1-10 than for trials 11-20. An analysis of variance (treatments $x$ levels) on the data for totals for trials $1-20$ showed no significant difference between high predictability and low predictability $(F=1.34)$ or between $\operatorname{sex}(F=2.2$, mean squares, Appendix, page 54). For trials 1-10 only, there was no significance for predictability variable (FCI), or for sex variable ( $F=2.31$ : mean squares, Appendix page 55). For trials 1l-20 only, $F<1$ for both sex and predictability; F. was 2.06 and $p>10$ for interaction (see mean squares, Appendix, page 56).

Time

The means of the amount of time in seconds taken by subjects in the experiment are shown in Table 4 . The means tend to show that all subjects took less time for the second 20 trials; they also show that while the total time for twenty trials is the same for the two conditions, females took much longer time in Condition No. 2 (low predictability). The data were treated to an analysis of variance (three factor mixed design, predictability, sex. trials, with repeated measures on one factor, trials). Results showed no difference for high predictability vs. low predictability $(F<I)$. While females tended to take longer total time than males for all trials for both conditions, this difference was not significant $(F=3.8$, df $1 / 16$, 
TABIE 4

MEANS OF AMOUNT OF TINE IN SECONDS TAKEN

DURING TRIALS

\begin{tabular}{|c|c|c|c|c|c|c|}
\hline \multirow[b]{2}{*}{ r. } & \multicolumn{3}{|c|}{ High Predictaoijity } & \multicolumn{3}{|c|}{ Low Fredictability } \\
\hline & $\begin{array}{c}\text { Trials } \\
1-10\end{array}$ & $\begin{array}{r}\text { Trials } \\
11-20\end{array}$ & $\underset{1-20}{\operatorname{Trials}}$ & $\underset{1-10}{\text { Trials }}$ & $\begin{array}{r}\text { Trials } \\
\text { IJ-20 }\end{array}$ & $\begin{array}{c}\text { Trials } \\
1-20\end{array}$ \\
\hline Males & 120.2 & 81.2 & 100.7 & 51.9 & $31 \cdot 3$ & 41.6 \\
\hline Fernales & 127.1 & 58.9 & 93.0 & 270.1 & 129.8 & 149.9 \\
\hline potals & 123.6 & 70.05 & 96.85 & 111.0 & 80.55 & 9.5 .75 \\
\hline
\end{tabular}




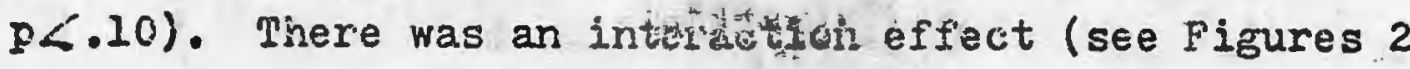
and 3 ) for both triale 1-10 and trials 1.1-20, females took longer time than males in the low prefletability condition $(F=5.06$, df $1 / 16, p<.05)$. Both male and female subjects took less time in both conditions in trials 11-20 than they did in trials $1-10 \quad(\xi=12.01$, df $1 / 16, p<.005$, see mean squares, Appendix page 57 ).

Table 5 shows the percentage of maximum allotted time for each 10 trials if all shocks were taken automatically every 30 secs. with each shock lasting 2.5 secs. (total 325 secs.). A treatment by levels design of analysis of variance on the amount of change in time between trials 1-10 and trials 11-20 was not significant for high predictability vs. low predictability $(F=1,56)$ or for sex $(F=2.21$, df $1 / 16, p>.10$, mean squares, sppendix page 58$)$.

\section{Anxiety measures}

To see if the two instruments were measuring the same state anxiety, a Pearson Product-Noment Correlation was run between scores of the Zuckerman Multiple Affect Adjective Check Iist and scores on the Wolpe self rating SUD Scale: there was significant correlation $(r=.4924$, df $18, p<.05)$.

Wilcoxon t-tests showed all subjects (both conditions) to have lowered their SUD anxiety ratings significantly after the first 10 trials ( $p<.05,2$ tail) and again after the last 10 trials ( $p<.01,2$ tail). Therefore, anxiety 
Fig. 2 Interaction effect retween sex and predictability on total time in seconds taken for trials $1-10$. 


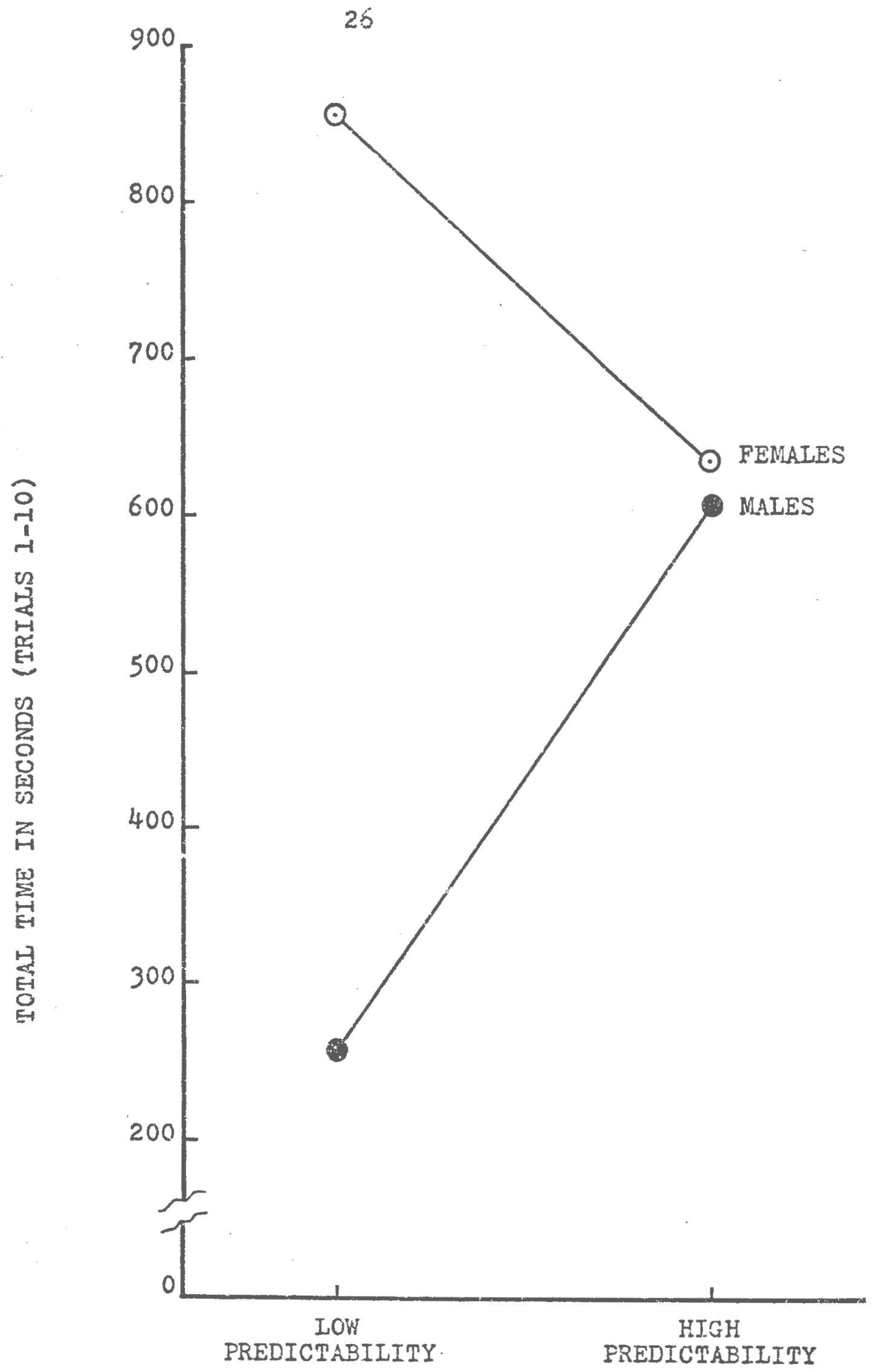


Fig. 3 Interaction effect between sex and predictability on total time in seconds taken for trials i1-20. 


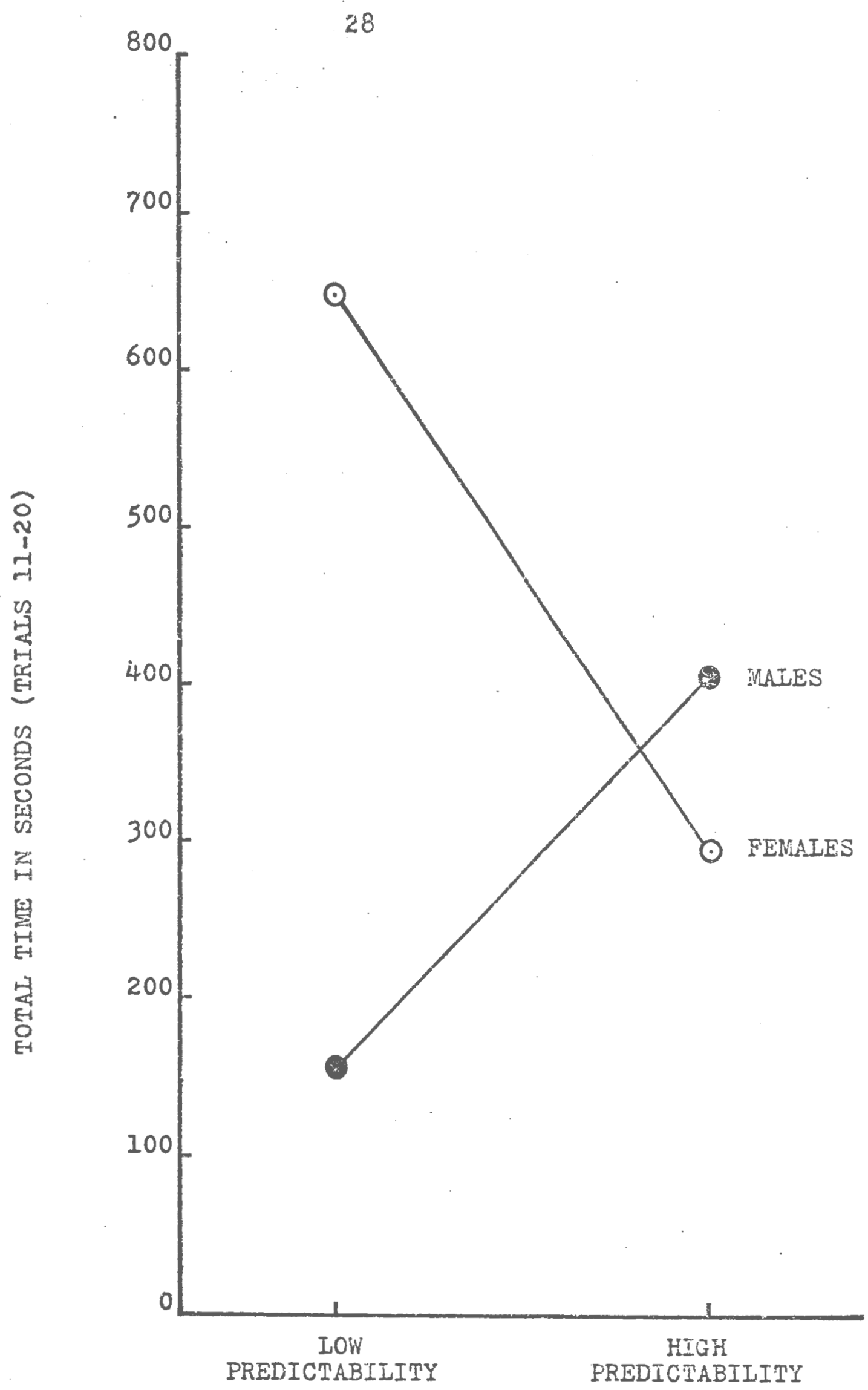


TABLE 5

PERCENTAGES OF MAXILUM ALIOTMED IIME (325 secs). FOR EACH 10 TRIALS TAKEN BY SUBJECIS

\begin{tabular}{|c|c|c|c|c|c|c|}
\hline \multirow[b]{3}{*}{ Miales } & \multicolumn{3}{|c|}{ High Predictability } & \multicolumn{3}{|c|}{ Low Predictability } \\
\hline & $\begin{array}{c}\text { Trials } \\
1-10\end{array}$ & $\begin{array}{r}\text { Trials } \\
11-20\end{array}$ & $\underset{1-20}{\text { Trials }}$ & $\underset{1-10}{T r i a l s}$ & $\begin{array}{r}\text { Trials } \\
11-20\end{array}$ & $\underset{1-20}{\text { Trials }}$ \\
\hline & $36.04 \%$ & $25.04 \%$ & $30.54 \%$ & $15.96 \%$ & $9.62 \%$ & $12.79 \%$ \\
\hline Females & $39.08 \%$ & $18.14 \%$ & $28.62 \%$ & $52.18 \%$ & $39.96 \%$ & $46.07 \%$ \\
\hline Totals & $37.56 \%$ & $21.59 \%$ & $29.58 \%$ & $34.07 \%$ & 24.790 & $29.43 \%$ \\
\hline
\end{tabular}


as measured by Wolpe's SUD scale was being uniformly lowered for all subjects after the first 10 trials and again after the next 10 trials.

Because $r=.4924$ is low, separate statistical tests were applied to the WOIpe SUD scale measures and to the Zuckerman measures. A Mann-Whitney U Test showed no significant differences between males and females in SUD Scale ratings during pre-test before trial 1 or in the interval after trials 1-10. There was a difference in the Zuckerman scores. Females were more anxious than males when Zuckerman scores (see Table 6 for means) were submitted to a treatment by levels analysis of variance $(F=8.19$, df 1/16, $<<.001$ : see mean squares Appendix, page 59); and also significant with a t test $(t=2.614$, df $18, \propto$ beyond $.02,2$ tail). The mean for females in low predictability is the highest of all indicating they were more anxious than both males and females in either condition.

\section{Millamp settings}

The means of milliamp levels set by subjects are shown in Table 7. Both males and females had a higher mean shock level for trials 11-20 than they did for triais 1-10. The means for both sexes were almost the same for trials and conditions. The means for low predictability are higher than for high predictability. The data did not vary as a function of high predictability vs. low predictability, or of sex, but did as function of trials (analysis of variance 
TABLE 6

BEAN ANXIETY SCORES ON ZUCKERIMAN MUETIPLE

AFFECT ADJECTIVE CHECK IIST

\begin{tabular}{|l|c|cc|}
\hline \multirow{2}{*}{ Males } & High Predictability & Low. Fredictability & Total \\
\cline { 2 - 4 } & 4.2 & 5.2 & 4.7 \\
Temales & 6.4 & 9.4 & 7.9 \\
& 5.3 & 7.3 & 6.3 \\
\hline
\end{tabular}




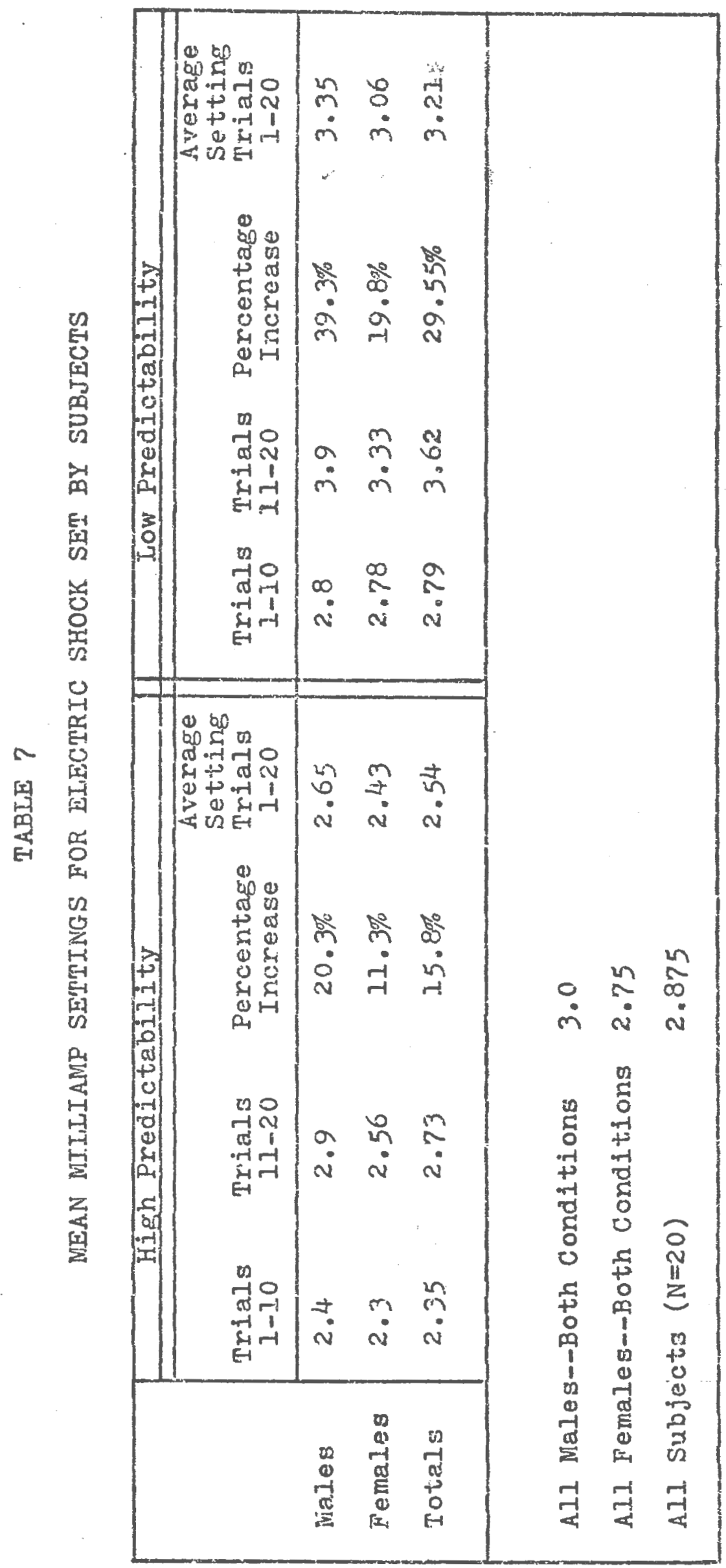


$\mathrm{F}=17.92$, df $1 / 16, \mathrm{p}<.001$, siendear squares, Appendix, page 60).

A series of Pearson Product-Monent Tests on the data showed no correlations between measures of anxiety (neither Zuckernan nor wolpe) with measures of time, milliamp settings, or number of self-administered shocks (see Appendix, page 62).

Paper and pencil data

These results appear in pables 8 and 9. The data in Table 9 were rated by four judges f for pleasure, - for pain, = for equal or midway between pair and pleasure. The judges were two professors of psychology and two practising clinical psychologists. A statistical test for the difference between proportions on the judges' ratings showed that thrse females out of five in low predictability condition experienced the shock experience as pleasure $(z=-2.0, p=.05,2$ tail).

\section{Discussion}

The results of this study showed that huwan subjects, when faced with inevitable punishment, and given a high degree of controllability of that punishment, behave the same way whether the punisiment is predictable or non-predictable. The low predictability subjects (no Faming signel) did not self-adrninister more shooks than the high predictability subjects as hypothesized; nor did they attempt to self-administer more shocks. While others 


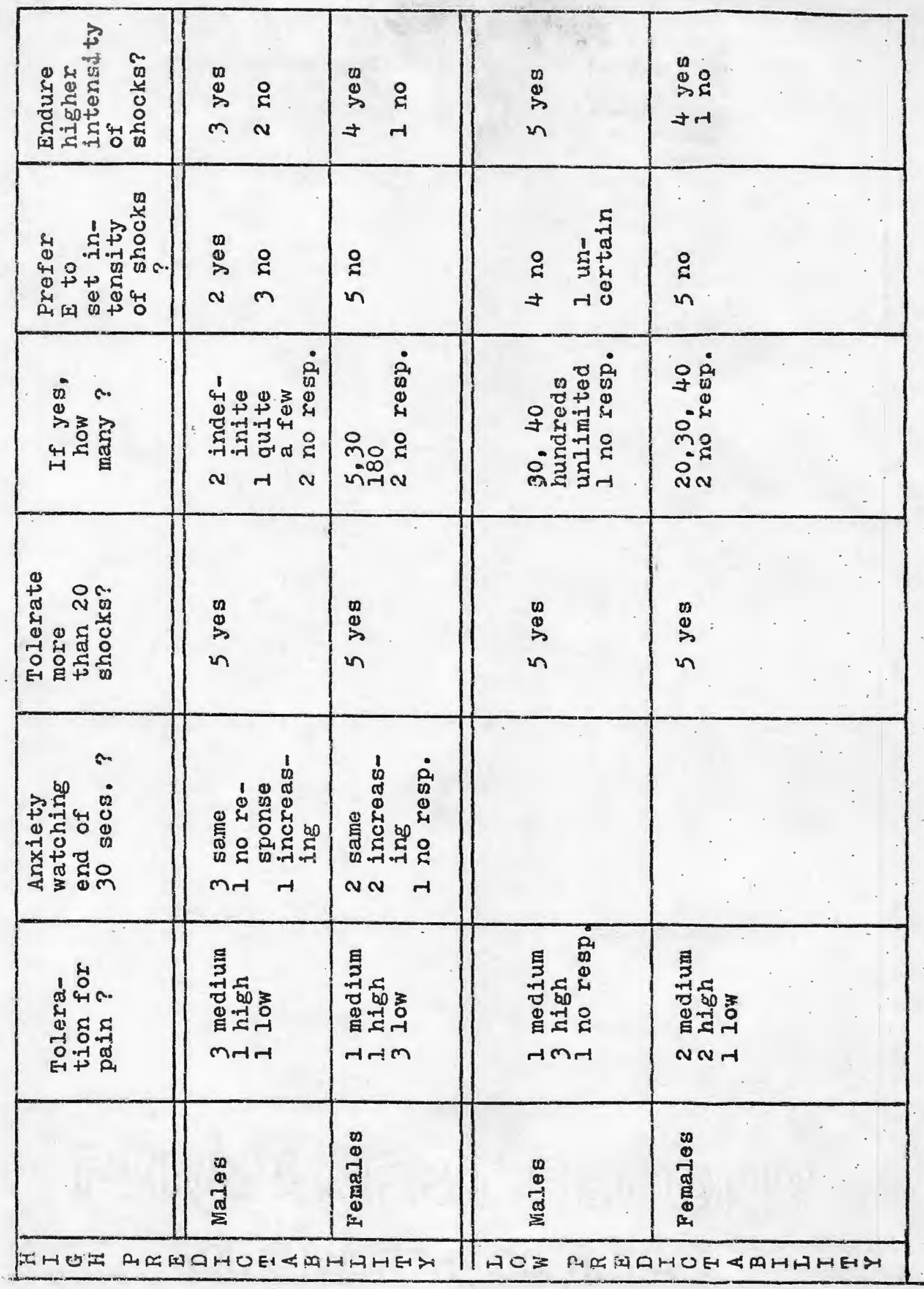


TABIE 9

SUBJECTIVE FOST-TEST DESCRIPTIONS OF

SHOCK EXPERIENCE

\begin{tabular}{|c|c|}
\hline $\begin{array}{l}\text { Males } \\
\text { High } \\
\text { Predicta- } \\
\text { oility }\end{array}$ & $\begin{array}{l}\text { 1. Pain } \\
\text { 2. Pain } \\
\text { 3. Slight Pain } \\
\text { 4. Aversive-to pain } \\
\text { 5. At first pleasurable, then less so }\end{array}$ \\
\hline $\begin{array}{l}\text { Females } \\
\text { Low } \\
\text { Predicta- } \\
\text { bility }\end{array}$ & $\begin{array}{l}\text { 6. Second half was relatively higher } \\
\text { shock than first half (Couldn't go } \\
\text { too far beyond second half } \\
\text { 7. Mid way between pain and pleasure } \\
\text { 8. Pain } \\
\text { 9. Pain } \\
\text { 10. Pain--discomfort }\end{array}$ \\
\hline $\begin{array}{l}\text { Males } \\
\text { Low } \\
\text { Predicta- } \\
\text { bility }\end{array}$ & $\begin{array}{l}\text { 11. Slight pain } \\
\text { 12. More or less disoleasure } \\
\text { 13. It wasr't pleasure, but not pain } \\
\text { 14. Combination. Not aversive, but } \\
\text { different } \\
\text { 15. Anxiety provoking--aversive }\end{array}$ \\
\hline $\begin{array}{l}\text { Females } \\
\text { Low } \\
\text { Predicta- } \\
\text { bility }\end{array}$ & $\begin{array}{l}\text { 16. Started as pain, then intriguing } \\
\text { and pleasurable } \\
\text { 17. Mixture of both,--more toward plea- } \\
\text { surable overwhelming desire not } \\
\text { to wait at shock No. } 5 \\
\text { 18. Irritating. Seemed milder 2nd half } \\
\text { 19. Pain } \\
\text { 20. Pleasure }\end{array}$ \\
\hline
\end{tabular}


Lockard, 1963, Perkins et al, 19683; Badia, 1967; Knapp et al, 1959) have shown that receiving shocks without a warning signal is more aversive, and while in this experiment the absence of a timer (low predictability) should have been more aversive, the results in this experiment concerning high vs. low predictability showed no difference. The difference in conditions may have been negated by the element of controllability. Subjects in both conditions had the same opportunity to push the button and self-administer shocks, which they did. This finding lends support to the studies of Haggard (1943) and Pervin (1963) who showed that human subjects preierred self-administered vs. experimenter-administered shocks. Perhaps the expected effect of aversiveness because of no warning signal in this study could have been accentuated by having the behavior of subjects pushing the button followed by delayed shock, either fixed delay or variable delay, rather than by immediate shock. D'Amato and Gumenik (1960) had found randomly delayed shock to be more aversive and unpleasant than immediate shock. Research investigating the delay of shock along with an element of controllability such as was present in this experiment has not been done.

The results of this experiment also showed that all subjects preferred to shock themselves rather than wait for automatically delayed shocks, and that this preference increased over trials. The subjects gave themselves an average of 8.2 out of the 10 possible shocks over the first 10 trials, and this increased to an average of 9.45 shocks 
for the next 10 trials. Subjestwerthecked during pretrial when establishing a level of aversity. Several shocks were required pre-trial, because the experimenter had the subjects experience the quick onset and duration of a shock at whatever level was set because this quick onset was different from the aversive experience of slowly, gradually increasing the shocis level: Obviously, adaptation was occurring. It might also be said that adaptation was taking place in the experimental condition over trials because 18 of 20 subjects set their MA level higher for the second 10 trials. After running all subjects, the author has speculated that, because of the pre-trial shocks, the subjects were possibly starting trials 1-10 with "learned helplessness," such as reported by Overmeir and Seligman (1967) who found that prior exposure of dogs to inescapable shock resulted in interference with subsequent escape/avoidance learning.

Since the number of self-acministered shocks in a fixed number of shocks situaticn tends to be related directly to the anount of time taken to receive the shocks, the data on time also did not distinguish the low and high predictable subjects. It is an unfortunate limitation of the design that trial-to-trial data were not recorded.

Seventeen of twenty subjects took less time for the second ten trials. Since no trial-to-trial data were collected, it is not known whether this behavior may have followed the U-shaped curve reported by Cook and Barnes (1964), 
but this finding suggests thetsif trials $11-20$ the knowledge that the last trials were due may have motivated subjects "to get it over. with." Is intersting as shown in Figure 1 that females in low predictability self-administered significantly fewer shocks than males, and also (Figures 2 and 3) spent significantly longer total time than males in both trials 1-10 and trials 11-20. This would suggest that the design of low predictability, rather than having created more aversiveness, effectively created less aversiveness for females in spite of the fact that their "severity" of punishment was higher. This is contrary to the results of cook and Bernard (1965) who found no sex differences in chosing a short delay of unavoidable punishment following a CS (light), even though they did report in females significantly more heart beats, fewer breaths, and higher GSR readings, (We are reminded that there is frequently no correlation between psychophysiological benavior and operant behavior.) Badia et al (1966) also reported no behavioral differences in sex in shock conditions. Therefore, a check on the raw data was made, the results showed that four of the females randomly assigned to low predictability were 22 years of age and that the fifth was age 43. Further analysis of the Zuckerman scores alone showed that these females had the highest anxiety scores. This is not to say that these females were "high anxious" or even "moderately severe" anxious, Zuckerman referred to scores of up to 8 as normal, and to scores of 8-12 as being of the "mild clinical anxiety" 
type, such as to be expected in atress response related to stage fright, perceptual isolatior, or (facing) an expected examination." this resul appear confusing because the two measures of anxiety correlated statistically, and because there were no statisticai differences in the ratings on the Wolpe SUD ratings. But, while significant, the correlation between Zuckerman and Wolpe SUD was low, $r=.4924$, and only 24 per cent of the variance was accounted for. It also suggests that the Zuckerman test is a more sensitive instrument for measuring state anxiety, because the females in low predictability experienced the experimental shocks as pleasurable.

Since the author asked no further questions of the subjects who experienced shock as pleasure, any explanation is tenuous. Also, the statistic to establish this "pleasure" is not robust, and the sample is small $(\mathrm{N}-5)$. These subjects vere more anxious, and they were in the more aversive of the two conditions: they had no CS (timer). Perhaps this low predictability increased their already higher state anxiety. The reduction of this higher anxiety by punishment may have been greater relative to the anxiety 'reduction of the other subjects who experienced pain, so much so that they sensed the punishment as tremendous relief, even pleasure. The fact that they also took longer time for the allotted number of shocks suggests that they may have preferred to experience this pleasure as long as possible between shocks. The evidence in this study that females 
with higher anxiety self-administered fewer shocks, took longer time in the shock situation, and found the experience one of pleasure rather than of pain, suggest that nore extensive research would be appropriate with a larger sampling of subjects, both sexes divided equally between measures of high and low anxiety.

Also, in a self-punishing, unavoidable situation, might there be variances of the numbers of self-administered shocks and amount of time spent to take shocks that would discriminate between "normal" and special populations of high anxiety such as alcoholics, suicidals, self-mutilators, neurotics, psychotics, and sociopäths?

The studies of Cook and Barnes (1964) and Cook and Bernard (1965) showed that subjects "tended to chose a shorter delay" when faced with inevitable shock; they also use the phrase that suojects "rush into shock." In this research, the subjects took 35.8 per cent of the allotted maximum time for the first 10 shocks and 23.2 per cent for the second 10 shocks, for an average of 29.5 per cent of the maximum time (see Table 5): these results do not justify the phrase that subjects are rushing into shock. Since Cook and Barnes did not assess state anxiety, it is not known how their subjects compared with the subjects in this study.

The average milliamp setting quoted in the iiterature (Table 1) is $1.75 \mathrm{MA}$, and the average shock duration is 0.36 seconds. These combine in an average "severity" of 
punishment (Church et $2.1,1967$ ) of 0.63 (1.75 MA $\times 0.36$ seccnds). The results of this study show that "severity" of punishment for females was 6.88 (2.75 $\mathrm{MA} \times 2.5$ seconds), for males 7.5 ( $3.0 \mathrm{MA} \times 2.5$ seconds); and for all subjects 7.19 (2.875 MA $\times 2.5$ seconds). Thus, the hypothesis is suppoeted that subjects when allowed to establish their own levels of electric shock will do so at a higher level than that established in the literature. A confounding contribution to these results may be the fact that electrode jelly was applied to the wrist to enhance conductance. Research by Green (1962) shows that shock threshold increased eight per cent with electrode jelly when using constant current (microamps). Therefore, the data were lowered by eight per cent, and the hypothesis was still supported; the total average MA setting for all subjects (Tabie 7) was raduced from $2.87 \mathrm{NA}$ to $2.645 \mathrm{MA}$, and the "severity" of punishment lowered to 6.61. Green also showed that with constant voltage, not microamps, the shock threshold was lowered by 60 per cent. The voltage for shocks cited in the literature is not always known. Therefore, the plea for universality of electric shock when used in research with humans should remain, ana all published studies should report voltage, current, duration, and whether or not electrode jelly is used.

There are other results, which, though not significant at the $P<.05$ level, tended also to suggest sex differences. Females tended to solf-administer fewer shocks for all trials $(F=4.25, p<.10)$ and females tended to take 
longer time for all trials $(s=3.51 \quad c<10)$. The amount of time change for trials 11-20, as against trials 1-10, appeared less for females than formales (F $2,0>10)$. The two hypotheses that low predictability subjects would self-administer more shocks, and would, (2) take less time in the shock situation, were not supported. Because females were more anxious, it is possible that not sex per se contributed to non-support of the hypotheses, but state anxiety; anxiety measures were not zccounted for in randomly assigning subjects to cells. Also, because of the sampling artifact of $\mathrm{N}=5$ in each of the four cells, replication of this study with a larger sample seems justified, before denying or discarding any of the hypotheses.

This study has been the first to combine high controllability (all suojects set their own shock levels; and all subjects could self-administer shocks) with a fixed number of unavoidable shocks of long duration ( 2.5 seconds) with and without a CS (timer). In spite of its limitations, it makes an important contribution to the psychology literature in suggesting methodology for future research. It also adds to the knowledge of human shock: all 20 subjects could have tolerated more than 20 shocks, with at least 10 subjects reporting toleration for from 30 more shocks to more shocks in the hundreds. Even though the "severity" of punishment was high, 16 subjects claimed they could have endured a higher intensity of shock, and orly two of 20 subjects would have preferred the experinenter to have established the shock level, even though toleration for pain (medium, high, low) 
appeared to be equally distributed (Table 8 ).

The limitations of this study have been mentioned. Until there is additional research as has been suggested, generalizations of the results would have to be limited to a similar biased sampling of subjects. 
APFENDIX 
Picture of Apparatus 
46

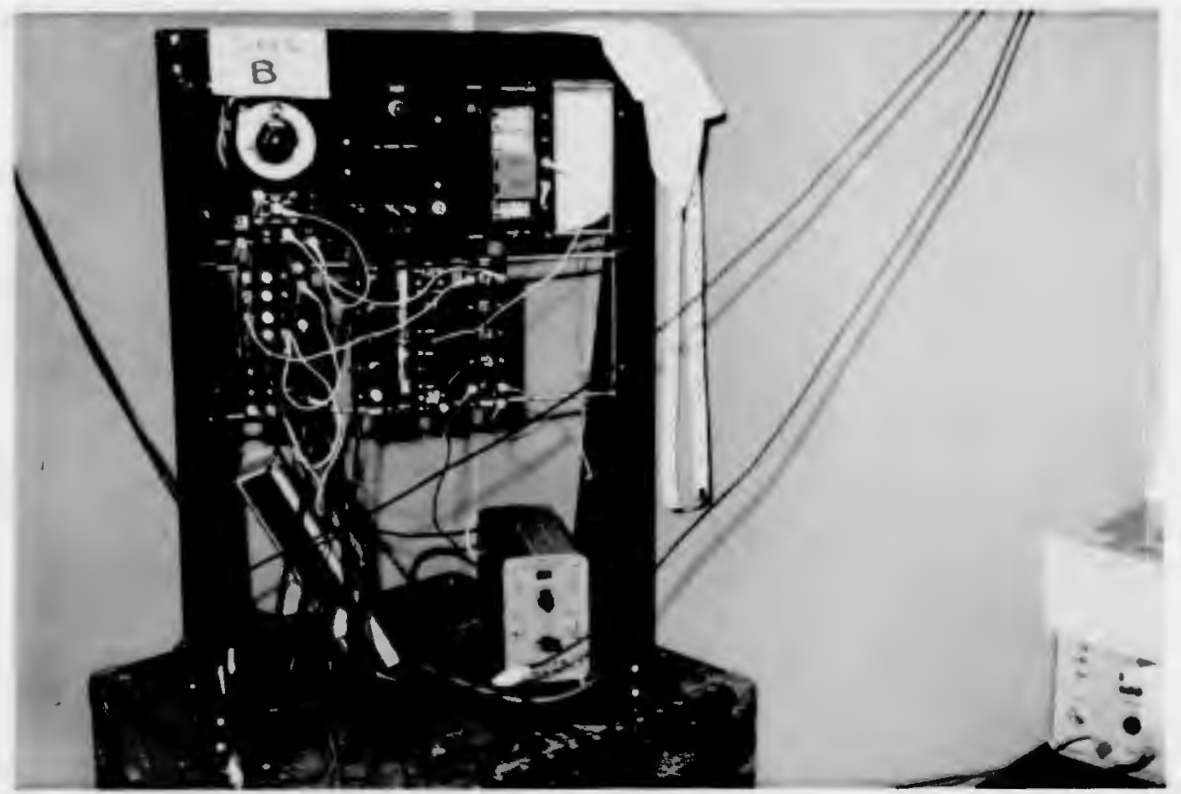




\title{
MUITPLE AFTECT
}

\section{ADJHCTVE CHECK LIST}

IN GENERAL FOR:A

\author{
Ey Marvin Zuckermen \\ and \\ Bernaró lubin
}

Name. Age....... Sex......

Date................. Highest grade completed in school.....

DERECTIONS: On this sheet you will find words which describe different kinds of moods and feelings. Mark an in the boxes beside the words which deseribe. huw you generally feel. Sone of the words may sound alike, but we want jou to cack all the words that describe your feelings. Work rapid!y.

PUELIEHED EY EDUCATIONA- AND INDUSTRIAL TESTIRG SEKVICE EOX 7234, SAN DIEGO, CGLIFORNIA 
Lactive

$\square$ adventurous

पaffectionate

LE arroid

[] agitated

[] agreaable

$\square$ aggressive

Dalive

$\square$ alone

[] amiable

[] amused

[i angry

$\square$ anmoyed

[] aพิul

$\square$ hashful

[] bitter

पblue

Z bo red

$5 \mathrm{calm}$

[] cautious

[J cheerfu!

- cis:in

[] complaining

[a] contenter

[Contrary

D 2001

Tooperative

[] critical

ijeross

[] cruei

[ daring

[ cespenate

[] destrojeù

[] dewoted

$\square$ disagreable

๑ discontented

Jiscouraged

Ei disgusied

E displeased

anergetic

Denryged

Denthusiastic

togrfui

Ifine
$45 \square$

$46 \square$ forlom

47 [ hink

$48 \square$ free

49 Iniendiy

50 I. Irightened

51 furious

$52 \square$ gay

53 $\square$ gentic

54 Igiad

$55 \square$ glocmy

$56 \square$ good

$57 \square$ gooc-natured

$58 \square$ gritn

$59 \square$ hapey

$60 \square$ healthy

$61 \square$ hopeless

62. $\square$ hostile

$63 \square$ inviatient

$64 \square$ incensed

$65 \square$ indignant

6) $\square$ insuined

67 Enterested

os $\square$ irritated

$69 \square$ jerlous

$70 \square$ iogrui

71 $\square$ kindly

$72 \square$ lonely

$73 \square$ lost

74 ¿loving

$75 \square$ low

76 ○lucky

$77 \square \mathrm{mad}$

$78 \square \mathrm{msan}$

$79 \square$ meek

80 [] merry

$81 \square$ mild

$82 \square$ miserable

83 - jnervous

84 abliging

$85 \square$ oriended

86 [ outraged

$87 \square$ paricky

88 Tpaitent
$89 \square$ pexceful

90 [ ylcased

$91 \square$ ploasart

$92 \square$ polite

$93 \square$ powerful

$34 \square$ quiet

$95 \square$ reokless

96 I rejected

97 L] rough!

$98 \square \operatorname{san}$

$90 \square$ sate

$100 \square$ satisfied

$301[$ secure

$102 \square \operatorname{sinaky}$

$103 \square \sin y$

$104[$ soothed

$105 \square$ steady

106 [ stubiorn

$10 \% \square$ storny

$108 \square$ strong

109 E suftering

$110:$ sullen

11. [] surk

in $\square$ sympatiotio

$133 \square$ tame

111 tender

$115 \square$ tense

i.je $\square$ terrible

117 [ torrified

$\$ 18 \square$ thougter

119 [ timid

$150 \square$ tormentro

121 E understinding

$122 \square$ uniagry

123 [.] unsociatie

124 5 upast?

$125[\mathrm{rrad}$

$120[\mathrm{krm}$

$127 \square$ \%कlo

$128 \square \cdots$

$120[3 \%$

$130 \square \mathrm{V}, \cdots$

$13: \square \cdots \cdots$

$132 \square 5 . \cdots 8$ 
NAME

M 5 $A G E$

S\#

GROUP \# 1 $\# 2$

OPERATIONAI

SEQUENCE

3. Ynot "A" Setiing MA.

5. Knob "A" Setting MA.

7. End of Test Counter Reacing (\#Shocks)

1. Holpe Sud Scale (Anxiety)

2. "Would you describe your normal toleration for pain as: INOW - MEDIUM, , HIGH ?"

4. Wolpe Sud Scale (Anxiety)

(2 Vin. Int.)

6. Wolpe Sud Scale (Anxiety)

8. (Group \#1 ONLY). "As you watched the approaching enc of 30 seconds on time "B". describe your ariziety, if any as INCREASING DECREASE , SAMEE

9. "Could you have tolerated more than 20 shocks?" YES , NO , IF YES, HOW MANY ?

10. "Would you have preferred $E$ to have set intensity of shoek? YES , NO ?"

11. "Could you have endured a higher intensity of shock without too much discomfort? YES , $\mathrm{NO}$ ?"

12. "Was this shock a pain or pleasure experience?" 
ANALYSIS OF VARIANCE ON SCORES OF NUMBER OF SELF $\rightarrow A D M I N I S T E R E D$ SHOCKS

\begin{tabular}{|c|c|c|c|c|}
\hline Source & $d f$ & SS & MS & $F$ \\
\hline Total & 39 & 113.73 & & \\
\hline Between S's & 19 & 59.28 & 3.12 & 1.16 \\
\hline $\begin{array}{l}\text { Fred, } \\
\text { Sey } \\
\text { Pred. } z \text { Sex } \\
\text { Error (B) }\end{array}$ & $\frac{\frac{1}{1}}{1}$ & $\begin{array}{r}0.03 \\
7.03 \\
7.22 \\
43.00\end{array}$ & $\begin{array}{l}0.03 \\
9.03 \\
7.22 \\
2.68\end{array}$ & $\begin{array}{l}0.01 \\
3.37 \\
2.69 .\end{array}$ \\
\hline Witrin S's & 20 & 54.50 & 2.73 & .2 .34 \\
\hline $\begin{array}{l}\text { Trials } \\
\text { Trials x Pred. } \\
\text { Trials x Sex } \\
\text { Trials x Pred, } \\
\text { x Sex } \\
\text { Exror }(w)\end{array}$ & $\frac{1}{1}$ & $\begin{array}{r}15.53 \\
2.02 \\
4.22 \\
0.03 \\
32.59\end{array}$ & $\begin{array}{r}15.63 \\
2.02 \\
4.22 \\
0.03 \\
2.04\end{array}$ & $\begin{array}{l}7.66 \% \\
0.99 \\
2.06 \\
0.14\end{array}$ \\
\hline
\end{tabular}

* $\mathrm{F}<.10$

$* * P<.025$ 
ANAIYSTS OF VARIANCE ON TOTAL NUMBER OF SEIFADMINISTERED SHOCKS FOR TRIALS

1-10 PLUS TRIAIS $11-20$

\begin{tabular}{|c|c|c|c|c|}
\hline Source & $\mathrm{ds}$ & SS & MiS & $F$ \\
\hline Total & 19 & 118.55 & & \\
\hline Predictability & 1 & 0.05 & 0.05 & 0.01 \\
\hline Sex & 1 & 18.05 & 18.05 & $4.25^{*}$ \\
\hline $\begin{array}{l}\text { Predictability } \\
\quad x \text { Sex }\end{array}$ & 2 & 32.55 & 32.55 & $7.68 * \%$ \\
\hline Error & 16 & 67.90 & 4.24 & \\
\hline
\end{tabular}

* P. $<.10$

$* *<.025$ 
ANAIYSIS OF VARIANCE ON AMOUNI OF CHANGE OF SELF-ADMINISTERED SHOCKS BETWEEN

$$
\text { TRIAIS 1-10 AND TRIAIS 12-20 }
$$

\begin{tabular}{lcccc}
\hline Source & df & SS & MS & F \\
\hline Total & 19 & 72.55 & - & $\ldots$ \\
Predictability & 1 & 6.05 & 6.05 & 1.64 \\
Sex & 1 & 6.05 & 6.05 & 1.64 \\
$\begin{array}{l}\text { Predictability } \\
\text { Sex }\end{array}$ & 1 & 0.4 .5 & 0.45 & 0.12 \\
Errox & 16 & 60.00 & 3.75 & \\
\hline
\end{tabular}


ANALYSIS OF VARIANCE ON TOTAI NUMBER OF ATPEMFTS TO SELF-ADMINISTER SHOCK (TRIALS 1-20)

\begin{tabular}{lrccc}
\hline Source & df & SS & liS & F \\
\hline Total & 19 & 153 & & \\
Predictabijity & 1 & 9.8 & 9.8 & 1.34 N.S \\
Sex & 1 & 16.2 & 16.2 & $2.21 \mathrm{~N} . \mathrm{S}$ \\
$\begin{array}{l}\text { Predictability } \\
\quad \text { S Sex }\end{array}$ & 1 & 9.8 & 9.8 & $1.34 \mathrm{~N} . \mathrm{S}$ \\
Error & 16 & 117.2 & 7.325 & \\
\hline
\end{tabular}


ANALYSTS OF VARIANCE ON TOTAI NUMBER OF AITEMPTS TO SEIJF-ADMINISTER SHOCK FOR

$$
\text { TRIAIS 1-20 ONLY }
$$

\begin{tabular}{lrrrr}
\hline Source & dr & SS & MS & $F$ \\
\hline Total & 19 & 108 & & \\
$\quad$ Predictability & 1 & 5.0 & 5.0 & 0.904 N.S. \\
Sex & 1 & 12.8 & 12.8 & 2.31 N.S. \\
$\begin{array}{l}\text { Predictability } \\
\quad x \text { Sex }\end{array}$ & 1 & 1.8 & 1.8 & 0.325 N.S. \\
Error & 16 & 88.4 & 5.53 & \\
\hline
\end{tabular}


ANALYSIS OF VARIANCE ON TOTAI NUMBER OF ATTEVIPTS

TO SELF-ADMINISTER SHOCK FOR

TRIALS 11-20 ONLY

\begin{tabular}{|c|c|c|c|c|}
\hline Source & $d f$ & SS & $M S$ & $F$ \\
\hline Total & 3.19 & 29.0 & & \\
\hline Predictability & 1 & 0.8 & 0.8 & $<1$ \\
\hline Sex & 1 & 0.2 & 0.2 & $<1$ \\
\hline $\begin{array}{l}\text { Predjetability } \\
\quad x \text { Sex }\end{array}$ & 1 & 3.2 & 3.2 & $2.06 *$ \\
\hline Error & 16 & 24.8 & 1.55 & \\
\hline
\end{tabular}


ANAIYSIS OF VARIANCE ON TINE IN SECS. (CONDITIONS, BY SEX, EY TRIAIS, HITH REPEATED MEASURES)

\begin{tabular}{|c|c|c|c|c|}
\hline Source & $d f$ & SS & MS & $F$ \\
\hline Total & 39 & 209.388 & & \\
\hline $\begin{array}{l}\text { Between S's } \\
\text { Pred. } \\
\text { Sex } \\
\text { Pred. x Sex } \\
\text { Error (b) }\end{array}$ & $\begin{array}{r}19 \\
1 \\
1 \\
1 \\
16\end{array}$ & $\begin{array}{r}165.493 .71 \\
11.77 \\
25.285 .81 \\
33.703 .83 \\
106.492 .3\end{array}$ & $\begin{array}{r}11.77 \\
25,285.81 \\
33.703 .83 \\
6.655 .7\end{array}$ & $\begin{array}{l}<1 \\
3.8 * \\
5.06 * *\end{array}$ \\
\hline $\begin{array}{l}\text { Within s's } \\
\text { Trials } \\
\text { Trials x Pred. } \\
\text { Trials x Sex } \\
\text { Trials x Sex } \\
\text { x Pred. } \\
\text { Error }(w)\end{array}$ & $\begin{array}{r}20 \\
\frac{1}{1} \\
1 \\
1 \\
16\end{array}$ & $\begin{array}{r}43.894 .29 \\
17.593 .83 \\
1.319 .06 \\
1.499 .41 \\
57.83 \\
23.424 .16\end{array}$ & $\begin{array}{r}17.593 .83 \\
1.319 .06 \\
1.499 .41 \\
57.83 \\
1.464 .01\end{array}$ & $\begin{array}{l}12.01 * * * \\
0.90 \\
1.02 \\
<1\end{array}$ \\
\hline
\end{tabular}

$* P<.10$

$* * P<.05$

$* * x<.005$ 
ANRLYSIS OF VARIANCE ON AMOUNT OF CHANGE IN TIME BETWEEN TRIALS 1-10 AND TRIALS 11-20

\begin{tabular}{|c|c|c|c|c|}
\hline Source & $d f$ & SS & $\mathrm{MS}$ & $F$ \\
\hline Total & 19 & 2843.25 & & \\
\hline Predictability & 1 & 223.79 & 223.79 & 1.56 \\
\hline Sex & 1 & 315.84 & 315.84 & $2.21 *$ \\
\hline $\begin{array}{l}\text { Predictability } \\
\quad x \text { Sex }\end{array}$ & 1 & 15.61 & 15.61 & $<1$ \\
\hline Error & 16 & 2288.01 & 143.00 & \\
\hline
\end{tabular}

* $P>.10$ 
ANALYSIS OF VARIANCE ON ZUCKERMAN MUIIIPLE AFFECT ADJECTIVE SCORES OF ANXIETY

\begin{tabular}{|c|c|c|c|c|}
\hline Source & $d f$ & SS & MS & F \\
\hline Total & 19 & 186.2 & & \\
\hline Predictability & 1 & 20.0 & 20.0 & 3.2 \\
\hline Sex & 1 & 51.2 & 51.2 & $8.19 *$ \\
\hline $\begin{array}{l}\text { Predictability } \\
\quad \times \text { Sex }\end{array}$ & 1 & 15.0 & 15.0 & 2.4 \\
\hline Error & 16 & 100.0 & 6.25 & \\
\hline
\end{tabular}


ANALYSIS OF YARIANCE ON SHOCK IEVEDS (UIIIIANES,

DATA TRANSFOSED TO MICROAMPS) SET BY SUBJECTS

(2X $2 \times 2$ ANOYA, WITS REFEATED

MEASURE ON ONE FACTOR).

\begin{tabular}{|c|c|c|c|c|}
\hline Source & $d f$ & SS & MS & $F$ \\
\hline Total & 39 & 710.834 .73 & & \\
\hline Eetween Ss & 19 & 631.726 .28 & 33.248 .75 & $<1$ \\
\hline $\begin{array}{l}\text { Pred. } \\
\text { Sex } \\
\text { Ered. X Sex } \\
\text { Error }(b)\end{array}$ & $\begin{array}{r}1 \\
1 \\
1 \\
16\end{array}$ & $\begin{array}{r}44.222 .23 \\
7.425 .63 \\
140.62 \\
579.737 .80\end{array}$ & $\begin{array}{c}44,222.23 \\
7,425.63 \\
140.62 \\
35,233.6\end{array}$ & $\begin{array}{l}1.22 \\
<1 \\
<1\end{array}$ \\
\hline Within Ss & 20 & 79.208 .50 & 3.955 .42 & 1.95 \\
\hline $\begin{array}{l}\text { Trials } \\
\text { Trials x Ered. } \\
\text { Irials x Sex } \\
\text { Trials x Fred. }\end{array}$ & $\begin{array}{l}\frac{1}{2} \\
1\end{array}$ & $\begin{array}{r}36,421.23 \\
5,3.30 .22 \\
4,100.62\end{array}$ & $\begin{array}{r}36,421.23 \\
5,130.22 \\
4,100.62\end{array}$ & $\begin{array}{c}27.92 \% \\
2.52 \\
2.02\end{array}$ \\
\hline $\begin{array}{l}\text { X Sex } \\
\text { Error }(y)\end{array}$ & 1.6 & $\begin{array}{r}950.63 \\
32.505 .80\end{array}$ & $\begin{array}{r}950.63 \\
2,031.61\end{array}$ & $<1$ \\
\hline
\end{tabular}

$* P<.001$ 
ANAIYSIS OF VARIANCE ON AYERAGE MIIJIAMP SETPINGS

( $\frac{1}{2}$ SUM OF TRIAIS 1-10 PLUS TRIALS 11-20)

\begin{tabular}{|c|c|c|c|c|}
\hline Source & $d f$ & SS & MS & $F$ \\
\hline Total & 19 & 146.03 & & \\
\hline Predictability & 1 & 75.12 & 75.12 & $17.23^{1}$ \\
\hline Sex & 1 & 0.89 & 0.89 & $<1$ \\
\hline $\begin{array}{l}\text { Predictability } \\
\quad x \text { Sex }\end{array}$ & 1 & 0.23 & 0.23 & $<1$ \\
\hline Error & 16 & 69.79 & 4.36 & \\
\hline
\end{tabular}


Zuckerman anxiety with SUD Scale anxiety

Zuckerman anxiety with interval SUD Scale anxiety $r=.4115 *$

Zuckerman anxiety with post-experiment SUD Scale anxiety

$r=.1725$

Zuckerman anxiety with time (trials i-10)

$\mathbf{r}=.3241$

SUD Scale anxiety with time (trials 1-10)

$r=.1582$

Zuckerman anxiety with time (trials 11-20)

$r=.2780$

Zuckerman anxiety with time (trials 1-20)

$x=.3259$

Zuckerman anxiety ith $M A$ setting (trials 1-10)

$r=0.01 .6$

Zuckerman anxiety with $B$ A setting (trials 11-20)

$r=-.09$

Zuckerman anxiety with average MA setting $r=-.0574$

MA setting with time, all subjects, (trials 1-10) $r=.0226$

Total time with total MA settings (trials 1-20) $r=.2941$

Males and females, MA setiings, (trials 1-10) $r=2056$

Zuckerman depression with SUD Scale anxiety

$r=.45$

Zuckerman depression with interval SUD Scale arxiety

$r=.20$

$$
\begin{array}{rl}
* & * P \\
* & <.05 \\
* & <.10
\end{array}
$$




\section{INSTRUCTIONS TO JUDGES}

S's received 20 shociss (Electric).

They received 10 shocks in first half experiment. Then 10 shocks after two min. interval.

After 20 shocks, they were asked to describe their experience as "Pain" or "Fleasure."

Attached are answers, which are variable. Please assign to their responses either + (pleasure), or - (pain), or =(equal, midway between pain and pleasure) 


\section{RESULTS OF FOUR UUDGES'S RATINGS}

1. Pain

Sign $\quad$ Count

2. Fain

3. Silght pain

4. Aversive--to pain

4

5. At first pleasurable, than less so

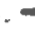

4

-
-4

$-4$

$\begin{array}{ll}+ & 3 \\ 1 & 1\end{array}$

6. Second half was relatively higher (shock) than first half, Couldn't go too far beyond second half.

7. Mioway betweer pain and pleasure

$$
4
$$$$
4
$$

3

8. Pain

9. Pair

10. Fain-adiscomfort

11. Slight Pain

12. More or less displeasure

13. It wasn't a pleasure, but not pain

-4
$=4$
-4
-4

4

4

4

4

4

$-4$

$-4$

14. Combination.. Not aversive, but different $=$

15. Anxiety provoking--aversive

4

$-4$

$=4$

4

4

16. Started as pain, then intriguing and pleasurable

17. Mixture of both--more toward pleasurable. Overwhelming desire not to wait at shock no. 5

18. Irritating. Seemed milder second half - 4

19. Pain

4

20. Pleasure

-4
$+\quad 4$




\section{REFERENCES}

Badia, P., McBane, B., Suter, S., and Lewis, P. Freference behavior in an immediate vs. variably delayed shock situation with and without a warning signal. Jouryal of Experimental Psychology, 1966, 72, 847-852.

Badia, P., Suter, S, , and Lewis, P. Preference for warned shocks information and/or preparation. Psychological Reports, $1967,20,271-274$.

Banks, R.K. and VogeI-Sprott, M. Effect of delayed punishment on an immediately rewarded response in humans. Journal of Experimental Psychology, 1965, 70, No. 4 $357-359$.

Berlyne, D.E. Conflict, Arousal, and Curosity, N.Y.: MCG raW-Hill, 1960.

Boe, E.E. and Church, R.M. Punishment: Issues and Experiments. N.Y.: Appleton-Century CroIts, 1968.

Brimer, C.J, and Kamin, I.J. Disinhibition, habituation, sensitization, and the conditioned emotionai response. Journal of Comparative and Physiological Psychology, 1963, 56, 508-516.

Brown, J.S, Martin, R.C. and Morrow, M.W. Self-punitive behavior in the rats: facilitaive effects of punishment on resistance to extinction. Journal of Comparative and Physiological Psychology, 1064, 57, $127-133$.

Erown, J.S. Factors affecting self-punitive locomotor behavior. In CampbeII, G.A. and Church, R.M. Punishment and Aversive Behavior. New York: AppletonCentury Crofts, 1969.

Camp. D.S. Some effects of an auditory cue in delayed punishment. Psychonomic Society, 1968.

Camp. D.S., Raymord, G.A., and Church K.M. Temporal relationship between response and punishment. Journal of Experimental Psychology, 1967, 74, 114-123. 
CampbeIl, B.A., Smith, N.F. arid. Heyin, J.R. Effects of punishment extinction of avos arce--avoidance conflict or vicious circle behavior? Journal of Comparative ard Physiological Psychology, 1966, 62 (3), 495-49:8, है,

Candland, D.G. Psychology: The Experimental Approach. N.Y.: MCGraw-Hill. 1968.

Cannon, W.B. The Wisdom of the Human Body. N.Y.: Norton, 1916. (Rev. ed., 1939).

Church, R.M. The varied effects of punishment or behavior, 1964. In Camp, D.S., Raymond, G.A., and Church, R.M., 1967. (See above).

Church, R.M., Raymond, G.A., and Beauchamp, R.D. Response suppression as a function of intensity and duration of a punishment, Iournal of Comparatjve and Physiological Psychology, 1967, 63, (1), 29-44).

Cook, J.O.., and Barnes, L.W., Jr., Choj.ce of delay of inevitable shock. Journal of Abnormal and Social Psychology, $1964,68,(6), 669-672$.

Cook, J.O. and Bernard, E.E. Choice of delay of consequences, Unpublished (personal correspondence), 1965.

Dale, P.E. Choice of delay of inevitabie punishment and its relation to marifest anxiety, grades and decision tine, 1963, MS thesis. In Cook, J.0. and Bernard, 1965, (see above).

I'Amato, M.R. and Gumenik, W.E. Some effects of immediate VS. randomly delayed shock on an instrumental response and congnitive processes. Journal of Abnormal ard Social Psychology, 1970. 50, (I), 64-6?.

Ferster, C.B. and Perrott, M.C. Behavior Principles. N.Y. Appieton-Century Crofts, 1968.

Green, R.T. The absolute thresholds of electric shock. Eritish Journal of Psychology, 1962, 53, 107-115.

Gwinn, G.T. The effects of punishment on acts motivated by fear. Journal of Experimental Psychology, 1949 , 39. $260-269$.

Fiaggard, E.A. Some conditions detemining adjustment during and readjustment following experimentally induced stress. Contempoxary psychology, edited by Tomkins, S.S., Camoriage, Wass., Harvard Univ. Press. 1943, 529-534. 
Hilgard, E.R. and Atkinson, P. M, N.Y. Harcourt, Brace and

Horney, K. The Neurotic Persorality of Our Time. N.Y.: Norton, 1937.

Hull, C.I., Principles of Behavior, N.Y. Appleton-Century, 1943, p. 151 .

Kanfer, F.H. and Phillips, J.S, Learning Foundations of Behavior Therapy, N.Y. John wiley \& Sons, Inc. 1970.

KimeI, H.D. and Pennypacker, H.S. Conditioned diminution of the unconditioned resporise as a function of the number of reinforcements. Journal of Experimental Psychology, 1962, 64, 20-23.

Knapp, R.K., Kause, R.H., and Perkins, C.C., Jr. Immediate vs. delayed shock in T-maze performance. Journal of Experimental Psychology, 1959, 58, 357-362. In Brush, F.K. Aversive Conditionin and Learning. N.Y.

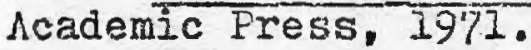

Iacey, J.I. Psychophysiological approaches to the evaluation of psychotherapeutic process and outcone. In E.A. Rubinstein and M.B. Parloff (Ed.s.), Research in Fsychotherapy, Vol. I, Washington, D.C.: American T'sychological Association, 1959.

Lang, P.J. Fear reduction and fear behavior: problems in treating a construct. In J.M. Shlien (Ed,), Research in PEychotherapy Voi. III, Washington, D.C.: haerican Fsychological Association, 1968.

Leviti, E.E, The Psychology of Anxiety. N,Y. Bobbs-Merrill Co., 1967.

Lockard, J.S. Choice of a warning signal or no warning signal in an unavoidable shock situation. Journal of Comparative and Physiological Psychology, 1963, 56 (3), $526-530$.

Melvin, K.B. Escape learning and "vicious circle" behavior as a function of percentage of reinforcement. Journal of Comparative and Physiological Psychology, $1964,58,248-251$.

Miller, N.E. Studies of fear as an acquirable drive: 1. fear as motivation and fear-reduction as reinforce.ment in the learning of new responses. Journal of Experimental Psychology, 1948, 38, 89-101. 
Mowrer, 0.H. Freparatory set (steetancy)-a determinant in motivation and learning. Esychological Review,

$1938,45,62-91$.

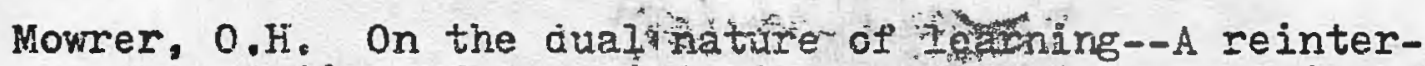
pretation of "conditioning" and "problem solving." Harvard Educational Revisw, 1947, 17, 102-148.

Howrer, 0.H. and Ullman, A.D. Time as a determinant in integrative learning. Psychological Review, 1945, 52. 61-90.

Overmeix, J.B. and Seligman, M.E.P. Effects of inescapable shock on subsequent escape and avoidance learning. Journal os Comparative Physiologicai Psychology, 1967, 63. 23-33.

Perkins, C.C., Jr., Levis, D.J., Seyman, R. Preference for signal-shock vs. shock-signal. Psychological Reports, $1963,13,735-738$

Fervin, I.A. The need to predict and control under conditions of threat. Journal of Fersonality, 1963, 32, 570-587.

Sidman, M. and Borer, J.J. The relative aversiveness of warning signal and shock in an avoidance situation. Jourmal of Abnormal and Social Psychology, 1957, 55, 339-344.

Skinner, B.F. The Behavior of Organisms. N.Y: AppletonCentury crofts, Inc., 1938.

Solomon, R.L. Punishment. Arnericar Psychologist, 1964 29. $239-253$.

Walsh, T.E, Fuman self-punitive behavior during uncertainty of delivery time of unavoidable shoris. Pilot study. Unpublished inanuscript, University of Rhode Island, Psychology Department, 1.970. 